\title{
Characterisation of Nox4 Inhibitors from Edible Plants
}

Authors

Affiliations
Philipp A. Kofler ${ }^{1}$, Haymo Pircher ${ }^{1}$, Susanne von Grafenstein ${ }^{2}$, Thomas Diener ${ }^{1}$, Monika Höll ${ }^{1,3}$, Klaus R. Liedl ${ }^{3}$, Karsten Siems ${ }^{4}$, Pidder Jansen-Dürr ${ }^{1,3}$

The affiliations are listed at the end of the article

\author{
Key words \\ - NADPH oxidase 4 \\ - Nox4 \\ - ROS \\ - inhibitors \\ dehydrogenase domain \\ - broken cell assay
}

received July 4,2012

revised October 26, 2012

accepted Dec. 6, 2012

\section{Bibliography}

DOI http://dx.doi.org/

10.1055/s-0032-1328129

Published online January 23,

2013

Planta Med 2013; 79: 244-252

(c) Georg Thieme Verlag KG

Stuttgart . New York .

ISSN 0032-0943

\section{Correspondence}

\section{Dr. Pidder Jansen-Dürr}

Institute for Biomedical Aging

Research

University of Innsbruck

Rennweg 10

6020 Innsbruck

Austria

Phone: + 4351258391944

pidder.jansen-duerr@uibk.ac.at

\section{Abstract \\ $\nabla$}

NADPH oxidases transport electrons from cytosolic NADPH through biological membranes to generate reactive oxygen species. NADPH oxidase 4 , broadly expressed in humans, is an interesting pharmacological target, since its activity is deregulated in several diseases, including pulmonary fibrosis, diabetic nephropathy, and cardiac hypertrophy. Whereas several candidate NADPH oxidase 4 inhibitors were recently described, most of these compounds are either unspecific or toxic. Here we set out to identify new NADPH oxidase 4 inhibitors from edible plants, in an attempt to decrease the number of hits with toxic side effects. We screened a compound library prepared from edible plants for new bioactives with the ability to inhibit the activity of NADPH oxidase 4. Using both cell-based and cell-free assays, we identified several compounds with significant inhibitory activity towards NADPH oxidase 4 . For selected compounds, the activity profile towards NADPH oxidase 2 and NADPH oxidase 5 was established, and controls were carried out to exclude general reactive oxygen species scavengers. A number of promising NADPH oxidase 4 inhibitors from edible plants was identified and characterised. Several new chemical entities are disclosed which act as NADPH oxidase 4 inhibitors, and the efficacies of our best hits, in particular

\section{Introduction}

\section{$\nabla$}

ROS induce damage to biological systems and were shown to contribute to ageing in cells. Aberrant ROS levels are linked to a variety of cancers [1] and many other diseases, e.g., vascular disease [2-6]. Whereas ROS are obligatory byproducts of mitochondrial oxidative metabolism, Nox2, the founding member of the Nox family $[7,8]$, was found responsible for the oxidative burst of phag- several diarylheptanoids and lignans, are comparable to the best available pharmacological NADPH oxidase 4 inhibitors. These findings will provide valuable tools to study mechanisms of NADPH oxidase inhibition.

\section{Abbreviations}

$\checkmark$

AR: $\quad$ Amplex Red

AUC: $\quad$ area under the curve

CL: chemiluminescence

DHE: dihydroethidium

DPI: diphenyleneiodonium chloride

$\mathrm{EC}_{50}$ : effective concentration at $50 \%$ activity

ETC: electron transport chain

HEK 293: human embryonic kidney 293 cells

MBP: $\quad$ maltose binding protein

NBT: nitrotetrazolium blue chloride

Nox: NADPH oxidase

Nox4DH: Nox4 dehydrogenase domain

PBMC: $\quad$ peripheral blood mononuclear cells

PMA: phorbol 12-myristate 13-acetate

ROCS: rapid overlay of chemical structures

ROS: $\quad$ reactive oxygen species

SF9: $\quad$ Spodoptera frugiperda insect cells

Supporting information available online at http://www.thieme-connect.de/ejournals/toc/ plantamedica

ocytes, where ROS are deliberately produced by Nox2 to enforce pathogen elimination $[7,8]$. In humans, the Nox family consists of seven enzymes, i.e., five NADPH oxidases (Nox1 through Nox5; for review, see $[7,9]$ ) and two Nox homologues (Duox1 and Duox2) [10], along with several subunits and regulatory proteins. All Nox proteins are transmembrane proteins with six (Nox1-Nox5) or seven (Duox1,2) transmembrane domains. In each case, four conserved histidines 
bind two heme groups that are essential for the electron transport from cytosolic NADPH through membranes to generate ROS. An integral part is also covered by the FAD and NADPH binding domains that are similarly conserved [2,7]. Both Nox2, a multisubunit NADPH oxidase best known for its role in the host defense against pathogens, and Nox5 require activation by upstream stimuli, such as PMA (Nox2) or calcium agonists (Nox5) for full activity; in contrast, Nox4, in complex with its obligatory subunit p22 $2^{\text {Phox }}$, is constitutively active [7]. Nox4 was identified in kidney [11] and was later found to be expressed in a variety of different cell types [12-19], and regulation occurs primarily at the mRNA level [20]. Whereas altered Nox4 activity has been found in a large variety of diseases, including pulmonary fibrosis, diabetic nephropathy (for review, see [4]), and benign prostatic hyperplasia [21], experiments with Nox4 $4^{--}$mice revealed a protective role of Nox4 in the vascular system [22], and Nox4 deletion was shown to predispose to diet-induced obesity [23].

Given the pleiotropic effects of Nox4 on a variety of physiological and pathophysiological processes, isotype-specific inhibitors of Nox 4 would be potentially very useful $[2,3,24,25]$. Whereas extracts of Piper sarmentosum regulate expression of Nox4 [26], inhibition of Nox 4 catalytic activity was not described for such extracts. Various efforts to search for new Nox4 inhibitors have been published in recent years, but so far there are no Nox4 inhibitors clinically available [21,27], although preclinical studies seem to support potential benefits in certain settings [28]. Also most known inhibitors are either unspecific or toxic $[29,30]$. However, there are attempts to chemically synthesise inhibitors from promising lead compounds, but the claimed effects so far remain uncertified $[24,25,31-34]$. This study aimed to identify formerly unknown Nox4 inhibitors from edible plants, in an attempt to satisfy ADMET criteria and avoid toxicity, which is becoming a high priority in this field [35].

\section{Materials and Methods}

$\nabla$

\section{Chemicals}

All reagents were purchased from Sigma-Aldrich, unless stated otherwise.

\section{Test compounds}

The majority of the compounds used for the screening were provided as purified compounds in solid state by AnalytiCon Discovery. For details of sample preparation, see Supplementary Methods as Supporting Information. As control compounds, we used DPI (Sigma), VAS2870 (Vasopharm), as well as honokiol and magnolol (both kindly provided by Hermann Stuppner, Innsbruck University). All control compounds were provided at $>95 \%$ purity.

\section{Cell culture}

Peripheral blood mononuclear cells were isolated fresh every day from volunteers and suspended in RPMI medium. Osteosarcoma cells (U2-OS) were acquired from ATCC, and human embryonic kidney (HEK 293 FT) cells were bought from Invitrogen. Both were grown in DMEM (Sigma) and provided with fresh medium every 2 and 3 days, respectively. DMEM was supplemented with $10 \%$ FCS (Biochrome AG, heat inactivated at $56^{\circ} \mathrm{C}$ for $40 \mathrm{~min}$ ), $4 \mathrm{mM}$ L-glutamine (Gibco), and 1/100 penicillin/streptomycin (Gibco). SF9 cells, a gift from Alexandra Lusser (Division for Molecular Biology, Medical University Innsbruck), were incubated in
SF9 II medium (Gibco) with $10 \%$ FCS, 1.4 mM glutamine, and pen/ strep at $27^{\circ} \mathrm{C}$.

\section{Nox dependent chemiluminescence}

Chemiluminescence was performed in white 96-well plates, tissue culture-treated, optical flat bottom (Matrix, Nunc, or Perkin Elmer), essentially as described before [36]. For details, see Supporting Information.

\section{ROS-scavenging assessment by DHE staining}

U2-OS cells were treated with rotenone and stained with dihydroethidium to assess ROS levels, as described [37]. For details, see Supporting Information.

Preparation of cell membranes and Nox4 in vitro assay Membrane fractionation and Nox4 activity measurement was performed similar to a method previously described $[24,27,34$, 38]; for details, see Supporting Information.

\section{Shape-based alignment}

In a retrospective analysis of the hits in the Nox-dependent chemiluminescence assay, we performed a shape-based analysis applying ROCS (version 3.1.1. OpenEye Scientific Software. http://www.eyesopen.com), as described $[39,40]$. For details, see Supporting Information.

\section{Results and Discussion}

$\nabla$

To assess the activity of Nox4 in intact cells, HEK cells expressing high levels of $\mathrm{p} 22^{\mathrm{Phox}}$ were transfected with an expression vector for Nox4. Stable transfection of HEK cells led to a significant increase of the Nox4 protein and activity, determined by chemiluminescence, which was sensitive to inhibition by the general Nox inhibitor DPI (Fig. 1S). This system was applied to determine the inhibitory activity of plant-derived compounds, selected from a compound library containing 3557 purified compounds, as outlined in Fig. $\mathbf{2 S}$ and briefly described below. For the first screening, a structural diverse subset of compounds derived from edible plants was selected, with a focus on compounds inside Lipinsky's Rule of Five. Results obtained with the diversity set were used to select additional compounds for screening, based on chemical similarity. The third screening was done with compounds mostly not structurally related to the hit compounds.

Selected experimental data are shown in $\mathbf{O}$ Fig. 1 for three selected plant compounds, representative of the activity spectrum (weak, intermediate, strong) obtained for the 14 best hits. DMSO vehicle had no effect on chemiluminescence activity, which was however significantly reduced by DPI when added at increasing concentrations ( $\boldsymbol{O}$ Fig. 1A). Under these conditions, compound ACD005 strongly suppressed Nox4 activity when assessed at a concentration as low as $0.5 \mu \mathrm{M}$ ("strong" inhibitory activity) with a clear dose dependency observed ( $\bullet$ Fig. 1 B). Under the same conditions, ACD018 induced a clear-cut inhibition of Nox4 activity when added at a concentration of $7.5 \mu \mathrm{M}$ ("weak" inhibitory activity) ( $\bullet$ Fig. 1 C, Table 1 ), whereas ACD212 displayed significant inhibitory activity when assayed at a concentration of $2.5 \mu \mathrm{M}$ ("intermediate" inhibitory activity), and residual inhibitory activity was still visible at a concentration of $0.5 \mu \mathrm{M}$ ( $\odot$ Fig. 1D). The results of all measurements are summarised in O Fig. $1 \mathrm{E}$ for 14 selected plant-derived compounds and the pharmacological Nox4 inhibitor VAS2870 [41,42], and approximative 


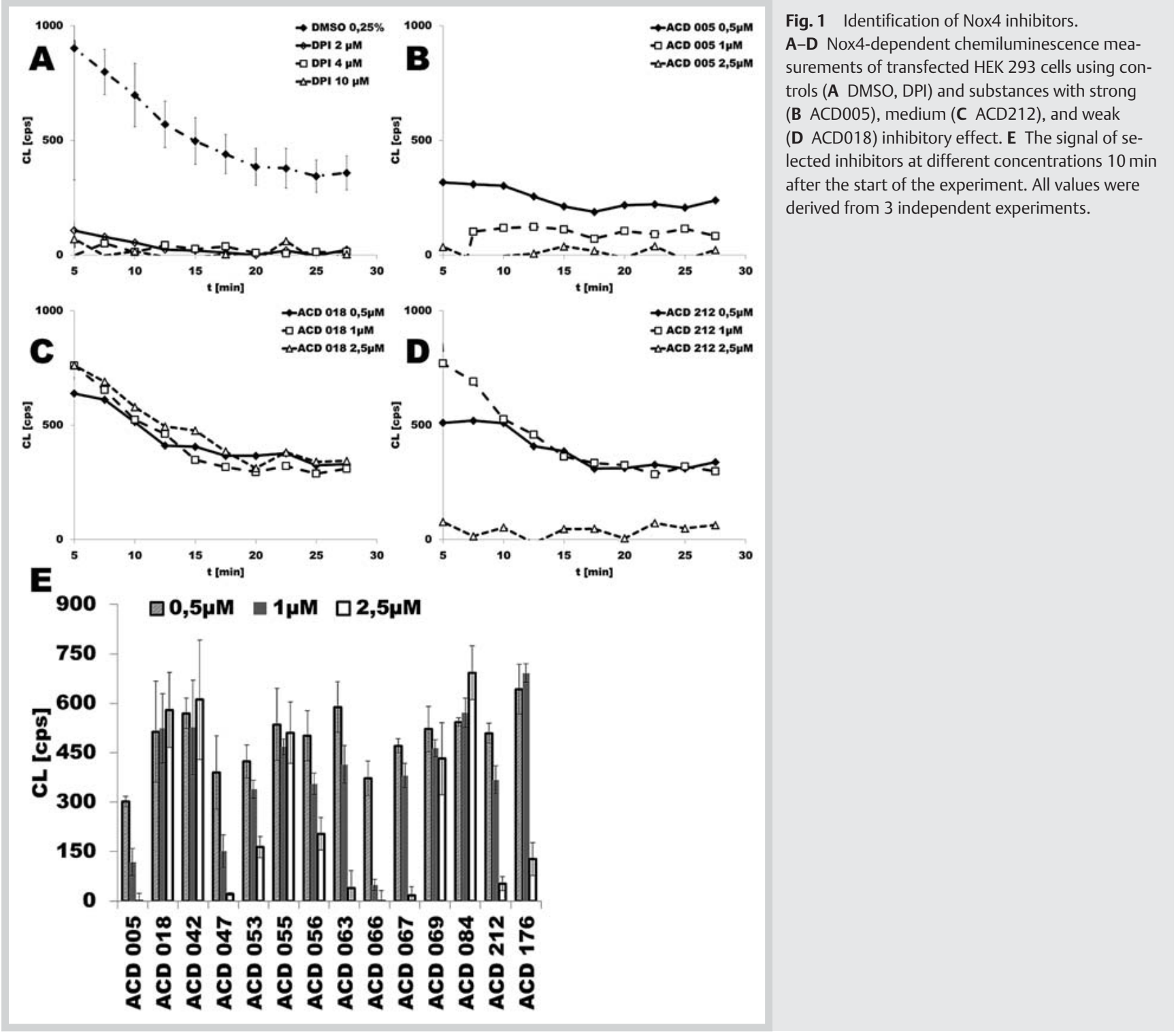

$\mathrm{EC}_{50}$ values were calculated ( $\bullet$ Table 1 ). Apocynin, gomisin C, magnolol, and honokiol, described as potential Nox4 inhibitors in the literature $[25,43,44]$, were included in our screening program; however, these compounds were at best moderately active in our assays. Thus, $\mathrm{EC}_{50}$ values were $60 \mu \mathrm{M}$ for apocynin, $25 \mu \mathrm{M}$ for gomisin C, $13 \mu \mathrm{M}$ for honokiol, and $150 \mu \mathrm{M}$ for magnolol. Because of the relatively low inhibitory activity in comparison to our best hits, these compounds were not considered further. Appropriate controls were included to identify inhibitors specific for Nox 4 activity. Thus, we set up a Nox2 activity screen based on normal PBMC isolated from healthy donors, in which Nox2 activity was stimulated by addition of PMA ( Fig. 2A), and compounds were applied at a concentration suitable for Nox4 inhibition (see above, 0 Table 1). Some of the Nox4 inhibitors, such as ACD042, did not inhibit Nox2 to any visible degree; in contrast, compound ACD018 displayed Nox2 inhibitory activity close to that of DPI, whereas VAS2780 displayed intermediate inhibitory activity ( $\odot$ Fig. 2B). The relative Nox2 inhibition by selected compounds is displayed in $\odot$ Fig. $2 C$.

To further address Nox specificity we also established a HEK-derived cell line constitutively expressing Nox5. Nox5 expression
Table $1 \mathrm{EC}_{50}$ of selected Nox4 inhibitors. This table summarises the calculated $\mathrm{EC}_{50}$ values for several inhibitors, as obtained in experiments with $\mathrm{HE}$ K-Nox4 cells. All values where derived from 3 independent experiments with 3 data points each, except for $\times 2$ independent experiments with 3 data points each and ${ }^{* *} 1$ experiment with 3 data points.

\begin{tabular}{|c|c|c|}
\hline Substance & Mean $[\mu \mathrm{M}]$ & $\pm S$ \\
\hline ACD 005 & 0.54 & 0.10 \\
\hline ACD $018^{*}$ & 7.42 & 6.59 \\
\hline ACD 042* & 2.06 & 0.76 \\
\hline ACD 047 & 0.87 & 0.42 \\
\hline ACD 053 & 0.92 & 0.28 \\
\hline ACD $055^{* *}$ & 1.88 & 0.26 \\
\hline ACD 056 & 1.62 & 1.12 \\
\hline ACD $063^{*}$ & 2.55 & 2.19 \\
\hline ACD 066 & 0.83 & 0.44 \\
\hline ACD 067 & 1.12 & 0.43 \\
\hline ACD 069 & 2.37 & 0.69 \\
\hline ACD 084 & 3.08 & 2.77 \\
\hline ACD $176^{* *}$ & 1.56 & 0.16 \\
\hline ACD 212 & 1.59 & 0.52 \\
\hline VAS 2870 & 2.65 & 1.13 \\
\hline
\end{tabular}




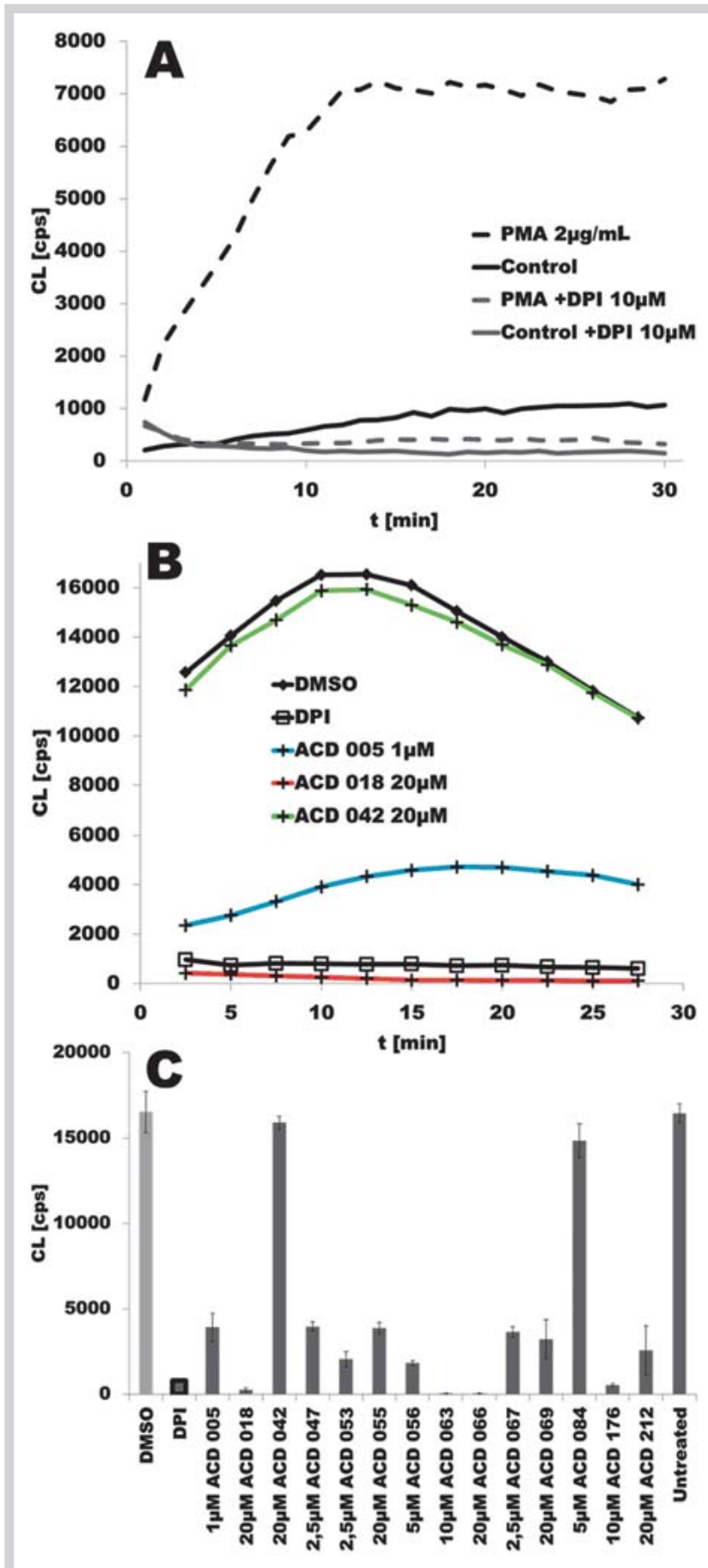

Fig. 2 Assessment of inhibitory activity towards Nox2. A Nox2-dependent chemiluminescence of PBMCs was measured after the addition of $2 \mathrm{\mu g} / \mathrm{mL}$ PMA in the presence of compounds at the indicated concentration. DMSO $0.1 \%$ was the vehicle control, DPI $10 \mu \mathrm{M}$ was the positive control. B A selection of typical Nox2-CL curves over time. $10 \mu \mathrm{M}$ DPI and $20 \mu \mathrm{M}$ ACD018 show strong inhibition, $1 \mu \mathrm{M}$ ACD005 and $20 \mu \mathrm{M}$ VAS2870 show reasonably moderate inhibition, $20 \mu \mathrm{M}$ ACD042 shows no inhibitory capacity similar to the vehicle control. C The chemiluminescence values of the above experiment at $t=10 \mathrm{~min}$ as a bar graph, comprising 14 Nox4 inhibitors, VAS2870, and standards (DMSO vehicle control, $10 \mu \mathrm{M}$ DPI, untreated control). (Color figure available online only.)

was verified, and Nox5 activity was detectable in these cells after addition of ionomycin (Fig. 3S), as described before [45]. In this

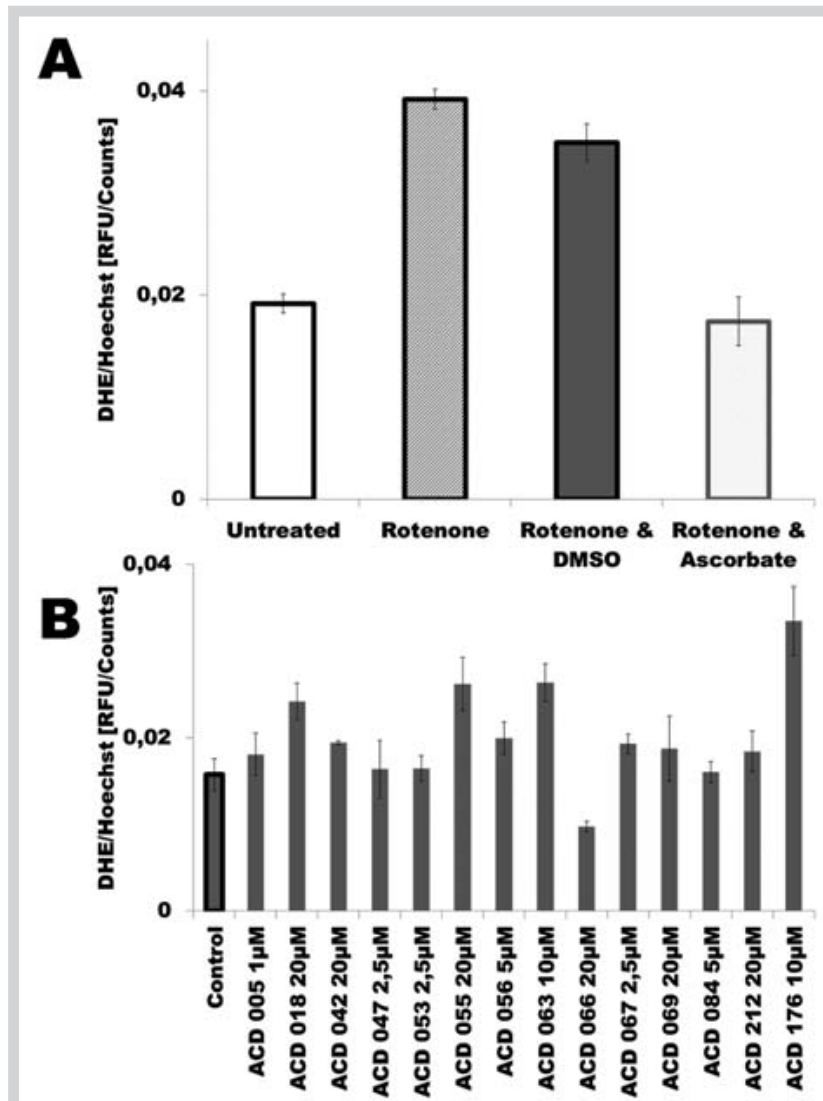

Fig. 3 Effects of candidate compounds on mitochondrial ROS. A ROS measurement of U2-OS cells after treatment with $0.2 \mu \mathrm{M}$ rotenone for $30 \mathrm{~min}$ (except for the untreated control). The rotenone control was otherwise untreated, $0.1 \%$ DMSO was used as the vehicle control. B DHE signal of 14 selected Nox4 inhibitors, the vehicle control ( $0.1 \%$ DMSO), and VAS2870 at the indicated concentrations. The untreated control (Panel A) has been subtracted as blank for all substances and the control in panel $\mathbf{B}$.

system, Nox5 activity was completely inhibited by DPI. Compound ACD063 displayed intermediate inhibitory activity, and VAS2780 was inactive (Fig. 3S).

An important source of potentially confounding effects is the well-known ability of many plant-derived compounds to unspecifically quench ROS, in many cases by direct chemical interaction (for recent review of ROS quenching mechanisms, see [46]). Such compounds, often referred to as ROS scavengers, neutralise a large variety of chemical ROS entities and therefore are expected to negatively interfere with the activity of most if not all experimental systems described in this communication. To assess the ability of plant-derived compounds to quench mitochondrial ROS production [37], mitochondrial ROS production was stimulated in U2-OS osteosarcoma cells by the addition of rotenone, an inhibitor of ETC complex I [47]. Subsequently, cells were stained with DHE, a redox-sensitive fluorescent dye recorded at $590 \mathrm{~nm}$ [37]. Cells were co-stained with Hoechst 33342, and fluorescence was recorded at $465 \mathrm{~nm}$. Fluorescence intensity of Hoechst 33342-stained cells is proportional to cell numbers and was used to normalise DHE fluorescence. Rotenone-induced signal was reduced to background by the addition of ascorbate ( Fig. 3A), consistent with previous findings [37]. In this experimental system, the selected compounds had no significant activity as ROS scavengers, with the exception of compound ACD066. 


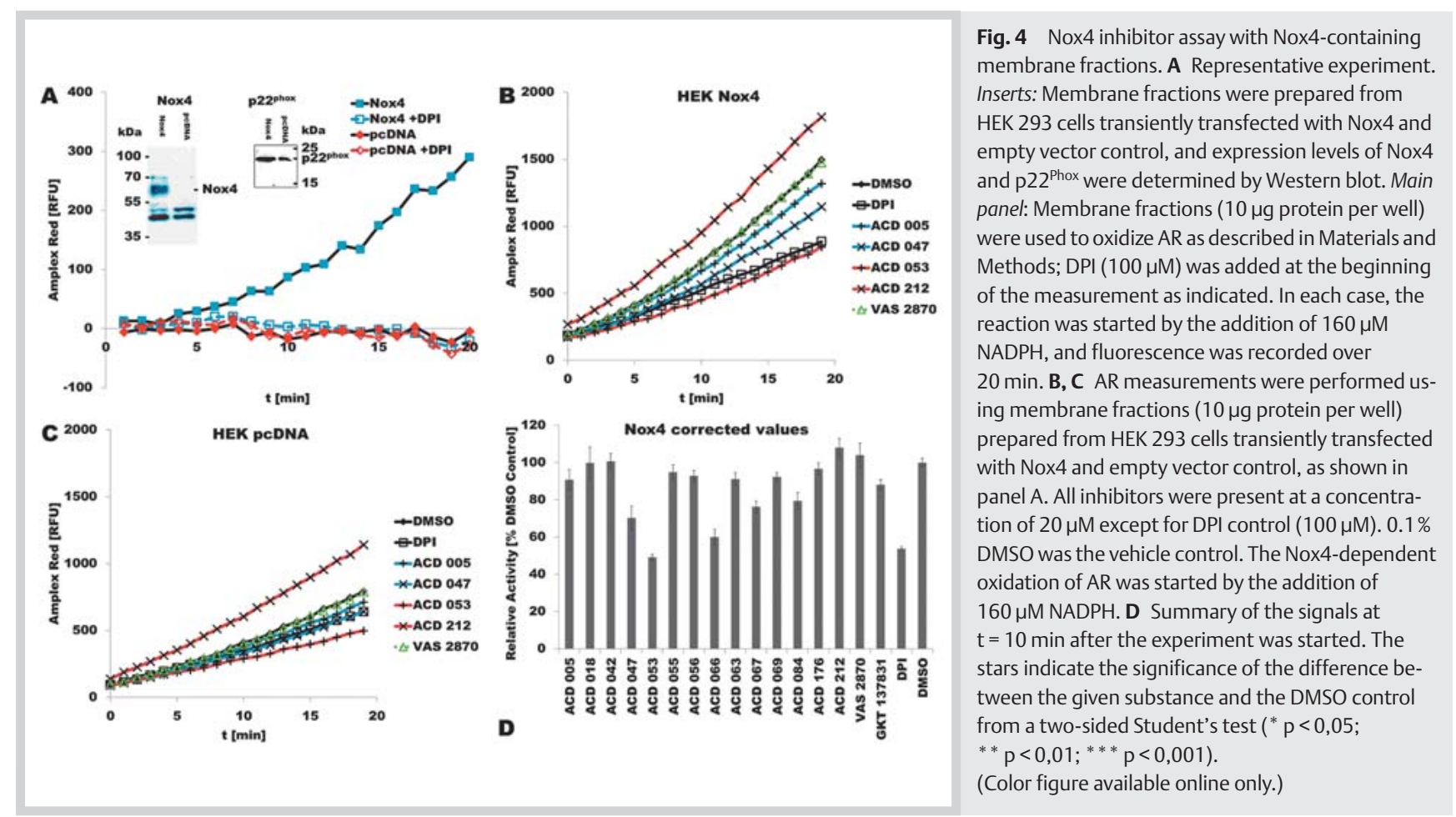

Our finding that ACD066 reduced the rotenone-induced DHE signal by roughly $50 \%$ suggests a more general mechanism rather than specific inhibition of NADPH oxidase activity for ACD066, which was therefore considered as a general ROS scavenger. Interestingly, the addition of some compounds, such as ACD176 and ACD055, even increased DHE fluorescence ( $\odot$ Fig. 3B); this observation was not investigated further as it is not directly related to Nox inhibition.

For further characterisation of the Nox 4 inhibitors identified in this study, we assessed their ability to inhibit Nox4 activity in vitro. To this end, membranes were isolated from Nox4-expressing HEK cells (HEK-Nox4) and control HEK cells (HEK-pcDNA), and Nox 4 content of the membrane fractions was verified by Western blot ( Fig. 4A). NADPH oxidase activity of these membrane fractions was assayed using AR fluorescence measurements, as described $[24,27,34]$. HEK-Nox4 derived membranes oxidised AR, and this activity was sensitive to DPI inhibition ( Fig. 4A), as expected. Addition of compounds ACD005, ACD047, ACD053, and ACD212 reduced Nox4 activity in vitro, and the inhibitory activity of ACD053 was similar to that of DPI, whereas VAS2870 showed rather weak activity in this assay ( Fig. 4B). Some of the compounds also inhibited the residual activity obtained with membranes from control (HEK-pcDNA) cells ( Fig. 4C), which most likely is not related to Nox4. For normalisation, the values obtained with control-transfected cells were subtracted from the respective values obtained with Nox4-expressing HEK cells. After normalisation, significant Nox4 inhibition was still obtained with compounds ACD053 and ACD047, whereas some compounds failed to inhibit Nox4 activity under these conditions ( Fig. 4D). Addition of ACD066 also significantly reduced AR fluorescence in this assay ( Fig. 4D); however, due to the proven capability of ACD066 to act as general ROS scavenger (see above, $\bullet$ Fig. $\mathbf{3}$ ), this compound was excluded from further analysis. DPI fully inhibited Nox 4 activity in intact cells (see above, 0 Fig. 1), but after addition of DPI to Nox4-containing membranes, roughly $50 \%$ of the chemiluminescence signal persisted, probably reflecting some background signals in the in vitro setting. Conceivably, the high background signal is due to the fact that much higher (roughly 10 fold) cell numbers are required for one measurement in the broken cell assay, compared to assays performed in intact cells; however, other reasons for the high background cannot be excluded.

Of note, the inhibitory potential of VAS2870 was strongly limited in these experiments, and ACD005 showed only an indistinct trend, relative to experiments in intact cells ( Fig. 4D); possible reasons for this are discussed below with the chemoinformatic analysis. The bioavailability and a compound's ability to penetrate into the cell is a big issue, and not all compounds that can inhibit an enzyme in vitro are expected to reach their protein target in intact cells. This is of particular importance for Nox4, since it is known that, unlike other members of the Nox family, a substantial proportion of Nox4 is found in intracellular membranes [7,48-50].

We also assessed the activity of selected compounds towards a recombinant fragment of Nox4, which retains the dehydrogenase reaction associated with Nox4 enzymatic activity. The protein fragment Nox4304-578 [51] was cloned in a baculoviral vector, expressed in SF9 insect cells as an MBP fusion protein and purified by affinity chromatography [51]. Upon incubation with NADPH, FAD, and NBT, significant dehydrogenase activity was detectable, which was abolished by boiling the recombinant protein prior to the assay (data not shown). The reaction could be triggered by addition of NADPH (Fig. 4S) or, alternatively, by the addition of FAD in the presence of NADPH (data not shown), confirming the dependency on both cofactors. Surprisingly, addition of DPI did not lead to sustained inhibition of the diaphorase activity associated with Nox4DH domain; instead, DPI addition in this setting even increased signal intensity (data not shown). The reasons why DPI fails to act as an inhibitor in this setting remain to be clarified. Whereas compound ACD084 significantly inhibited the 
Table 2 Selected compounds. Given in the table are the compound numbers as used in the paper in the first column. The second column gives the trivial name as known so far, the third column provides the order numbers from AnalytiCon Discovery. Column four shows the 2D chemical structure, and the last line provides the SMILE (Simplified Molecule Input Line Entry) string for each compound.

\begin{tabular}{|c|c|c|c|c|}
\hline $\begin{array}{l}\text { Compound } \\
\mathrm{Nr} \text {. }\end{array}$ & Name & Order Nr. & Structure & SMILES \\
\hline ACD 005 & - & NP-000520 & & $\begin{array}{l}\mathrm{O}[\mathrm{C} @ @ H]([\mathrm{C} @ H](\mathrm{OCC} 1 \mathrm{C}(\mathrm{C} 2=\mathrm{CC}=\mathrm{C}(\mathrm{O}) \mathrm{C}(\mathrm{OC})=\mathrm{C} 2) \mathrm{C} 3=\mathrm{CC} \\
(\mathrm{O})=\mathrm{C}(\mathrm{OC}) \mathrm{C}=\mathrm{C} 3 \mathrm{CC} 1 \mathrm{CO}) \mathrm{O} 4)[\mathrm{C} @ \mathrm{H}]([\mathrm{C} @ \mathrm{H}]([\mathrm{C} @ \mathrm{H}] 4 \mathrm{CO}) \mathrm{O}) \\
\mathrm{O}\end{array}$ \\
\hline ACD 018 & Bakuchiol & NP-007515 & & $\mathrm{OC} 1=\mathrm{CC}=\mathrm{C}(/ \mathrm{C}=\mathrm{C} /[\mathrm{C} @](\mathrm{CC} / \mathrm{C}=\mathrm{C}(\mathrm{C}) / \mathrm{C})(\mathrm{C}) \mathrm{C}=\mathrm{C}) \mathrm{C}=\mathrm{C} 1$ \\
\hline ACD 042 & Grindelic acid & NP-002752 & & $\begin{array}{l}\mathrm{CC} 1(\mathrm{CCC}[\mathrm{C} @] 2(\mathrm{C})[\mathrm{C} @] 3(\mathrm{O}[\mathrm{C} @ @](\mathrm{C})(\mathrm{CC}(\mathrm{O})=0) \mathrm{CC} 3) \mathrm{C}(\mathrm{C}) \\
=\mathrm{CCC} 12) \mathrm{C}\end{array}$ \\
\hline ACD 047 & - & NP-000261 & & $\begin{array}{l}\mathrm{CC}(\mathrm{C}(\mathrm{OC} 1 \mathrm{C} 2=\mathrm{CC}(\mathrm{OC})=\mathrm{C}(\mathrm{O}) \mathrm{C}=\mathrm{C} 2) \mathrm{C} 3=\mathrm{CC}=\mathrm{C}(\mathrm{O}) \mathrm{C}(\mathrm{OC})=\mathrm{C} 3) \\
\mathrm{C} 1 \mathrm{C}\end{array}$ \\
\hline ACD 053 & - & NP-002766 & & $\begin{array}{l}\mathrm{OC}(\mathrm{C}(\mathrm{OC})=\mathrm{C} 1)=\mathrm{CC}=\mathrm{C} 1 / \mathrm{C}=\mathrm{C} / \mathrm{C}(\mathrm{CC}(/ \mathrm{C}=\mathrm{C} / \mathrm{C} 2=\mathrm{CC}(\mathrm{O})=\mathrm{C}(\mathrm{O}) \\
\mathrm{C}=\mathrm{C} 2)=\mathrm{O})=\mathrm{O}\end{array}$ \\
\hline ACD 055 & $\begin{array}{l}\text { Dihydroyasha- } \\
\text { bushiketol }\end{array}$ & NP-003489 & & $\mathrm{O}=\mathrm{C}(\mathrm{C}[\mathrm{C} @ @ \mathrm{H}](\mathrm{O}) \mathrm{CCC} 1=\mathrm{CC}=\mathrm{CC}=\mathrm{C} 1) \mathrm{CCC}=\mathrm{CC}=\mathrm{CC}=\mathrm{C} 2$ \\
\hline ACD 056 & Gomisin J & NP-015225 & & $\begin{array}{l}\mathrm{CC} 1 \mathrm{C}(\mathrm{C}) \mathrm{CC} 2=\mathrm{C}(\mathrm{C}(\mathrm{OC})=\mathrm{C}(\mathrm{OC}) \mathrm{C}(\mathrm{O})=\mathrm{C} 2) \mathrm{C} 3=\mathrm{C}(\mathrm{C}=\mathrm{C}(\mathrm{O}) \mathrm{C}(\mathrm{OC}) \\
=\mathrm{C} 3 \mathrm{OC}) \mathrm{C} 1\end{array}$ \\
\hline ACD 063 & - & NP-012941 & & $\begin{array}{l}\mathrm{OC}(\mathrm{C}=\mathrm{CC}(\mathrm{CCCCC}(\mathrm{CCC} 1=\mathrm{CC}=\mathrm{C}(\mathrm{O}) \mathrm{C}=\mathrm{C} 1) \mathrm{OC}(\mathrm{C})=\mathrm{O})=\mathrm{C} 2) \\
=\mathrm{C} 2 \mathrm{O}\end{array}$ \\
\hline ACD 066 & - & NP-003620 & & $\mathrm{O}=\mathrm{C}(\mathrm{CCCCC} 1=\mathrm{CC}(\mathrm{O})=\mathrm{C}(\mathrm{C}=\mathrm{C} 1) \mathrm{O}) \mathrm{CCC} 2=\mathrm{CC}=\mathrm{C}(\mathrm{O}) \mathrm{C}(\mathrm{O})=\mathrm{C} 2$ \\
\hline ACD 067 & - & NP-003332 & & $\mathrm{O}=\mathrm{C}(\mathrm{CC}(\mathrm{O}) \mathrm{CCC} 1=\mathrm{CC}=\mathrm{C}(\mathrm{O}) \mathrm{C}(\mathrm{OC})=\mathrm{C} 1) \mathrm{CCC}=\mathrm{CC}=\mathrm{CC}=\mathrm{C2}$ \\
\hline ACD 069 & - & NP-012926 & & $\begin{array}{l}\mathrm{CC}(\mathrm{C}(\mathrm{C}(\mathrm{O} 1) \mathrm{C} 2=\mathrm{CC}=\mathrm{C}(\mathrm{O}) \mathrm{C}=\mathrm{C} 2) \mathrm{C}) \mathrm{C} 1 \mathrm{C} 3=\mathrm{CC}(\mathrm{OC})=\mathrm{C}(\mathrm{C}=\mathrm{C} 3) \\
\mathrm{OC}\end{array}$ \\
\hline ACD 084 & - & NP-003624 & & $\begin{array}{l}\mathrm{OC}(\mathrm{C}=\mathrm{CC}(\mathrm{CCCCC}(\mathrm{CCC} 1=\mathrm{CC}=\mathrm{C}(\mathrm{O}) \mathrm{C}(\mathrm{O})=\mathrm{C} 1) \mathrm{OC}(\mathrm{C})=\mathrm{O})=\mathrm{C} 2) \\
=\mathrm{C} 2 \mathrm{O}\end{array}$ \\
\hline
\end{tabular}


Table 2 Continued

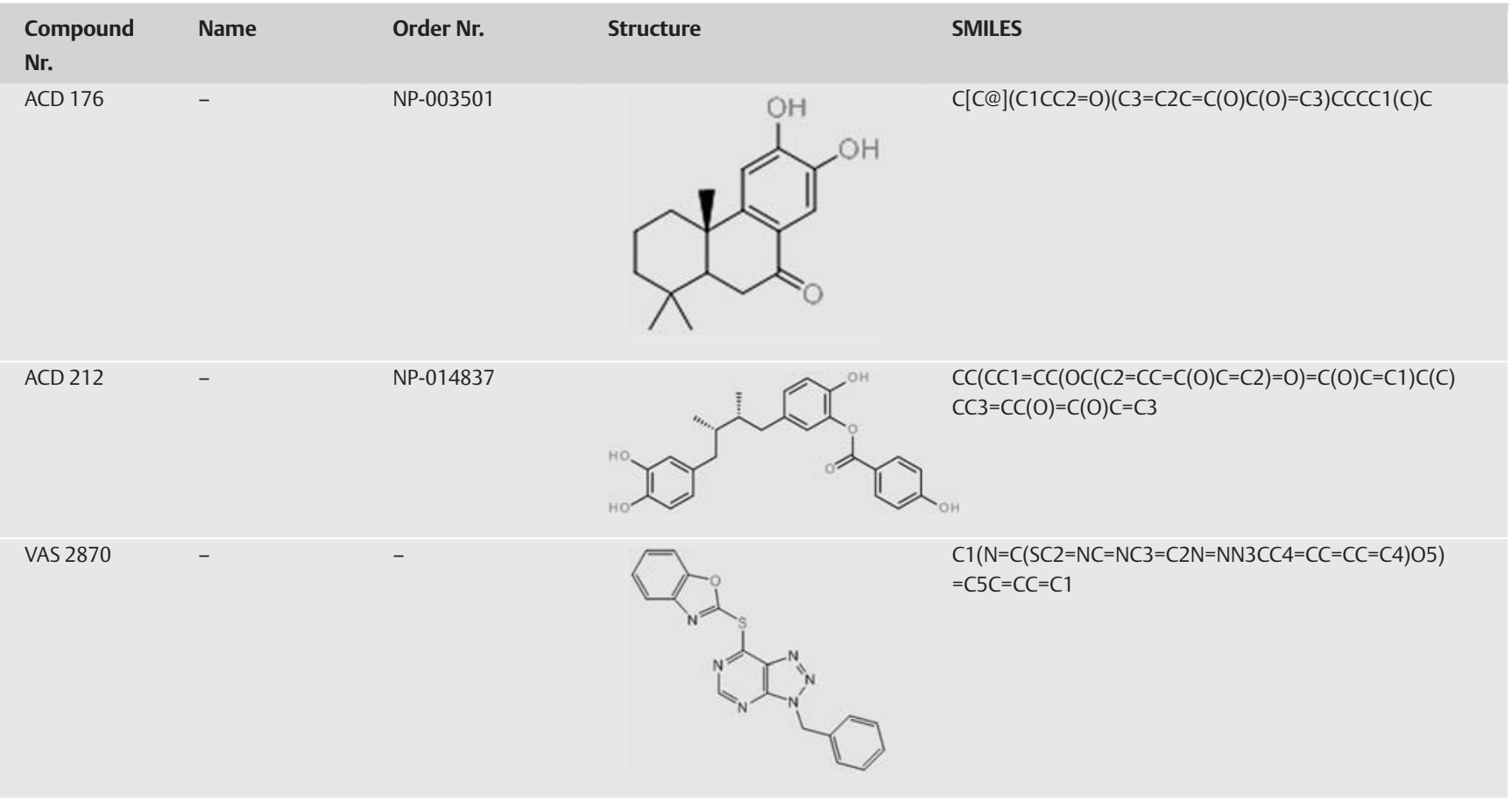

dehydrogenase reaction catalysed by Nox4304-578, compounds ACD005 and ACD063 displayed weak but significant inhibitory activity (Fig. 4S); in contrast, compounds ACD069 and VAS2870 were inactive in this assay (Fig. 4S). This may indicate that the mode of inhibition displayed by these inhibitors differs from the other compounds described in this communication. As was pointed out by Jaquet et al. [25], inhibition of Nox enzymes including Nox4 can occur at different stages, including depletion of substrate, interference with transcription or complex assembly, masking of the reaction product, etc. For compounds that inhibit Nox4 in intact cells but not in the Nox4DH assay, inhibition apparently involves Nox4 domains not present in the fragment. Accordingly, the mechanism of inhibition may differ between compounds described here and remains to be identified in all cases.

Plant-derived compounds described here can be assigned to several activity profiles: several compounds qualify as highly active Nox4 inhibitors, defined here by an $\mathrm{EC}_{50}$ below $1 \mu \mathrm{M}$. This includes ACD005, ACD047, and ACD053, all of which also inhibited Nox2 activity. Two additional compounds identified here, ACD042 and ACD084, are of potential interest, because they did not inhibit the activity of Nox2 nor Nox5. They may be considered as specific Nox4 inhibitors, although their $\mathrm{EC}_{50}$ is slightly higher than for the best Nox4 inhibitors described above. In quantitative terms, their activity is similar to the recently described Nox4 inhibitor VAS2870 [52], which in our hands displayed reasonable activity towards Nox4 and Nox2.

During screening as well as retrospectively, chemoinformatics tools were applied to guide selection of candidates and to characterize our best hits, respectively. In a shape-based alignment, we identified ACD018 and ACD067 as suitable query molecules to enrich hits within inactive compounds during the evaluation showing the highest area under the receiver operator curve value (Fig. 5S). A retrospective chemical characterisation was done by calculation of selected chemical descriptors allowing an estimation of the drug-likeness for oral uptake according to Lipinski [53] (Table 1S). ACD005 was the only compound showing clear violation of Lipinski's Rule of Five with more than 10 acceptors, more than 5 donors, and a molecular weight above $500 \mathrm{Da}$. This candidate Nox 4 inhibitor bears a sugar moiety and therefore is very hydrophilic which is reflected in a $\operatorname{low} \log \mathrm{P}(\mathrm{o} / \mathrm{w})$. In contrast, high $\log \mathrm{P}(\mathrm{o} / \mathrm{W})$ values are estimated for the compounds ACD018 and ACD212. Although these $\log P(0 / w)$ values are higher than the criteria of $\log \mathrm{P} \leq 5$, those compounds are classified as drug-like according to Lipinski as one violation is accepted.

The retrospective analysis of the identified hits relies on molecular descriptors calculated in silico. Chemical characteristics within the hits presented here give insight in the chemical requirement for Nox4 inhibitors ( Table 2). So, the occurrence of 6 diarylheptanoids (ACD053, ACD055, ACD063, ACD066, ACD067, and ACD084) and the presence of phenol substructures within 12 out of 14 presented compounds indicate that this substructure is beneficial for Nox4 inhibition. For ROCS, the high AUC values for ACD018 and ACD057 are caused by the presence of 4-substituted phenol substructures. This can be seen as a common characteristic within almost all actives except ACD042 and ACD005. In fact, ACD055, which is the only diarylheptanoid without hydroxylation at the aromatic rings, is less active $\left(\mathrm{EC}_{50}=1.88 \mu \mathrm{M}\right)$ than the chemically related compound ACD067 with a phenol.

For ACD005, the low AUC value is caused by the sugar moiety unique within the test set. ACD005 was characterised by high activity towards Nox4 in the chemiluminescence assay in the assay with intact cells ( Table 1 ) but a surprisingly low effect on the isolated membranes ( Fig.4D). We assume ACD005 to enter the intact cells although it violates the Lipinski's Rule of Five due to its sugar moiety. The glycosylation is a typical feature of natural products, and Lipinski's Rule of Five might not appropriately reflect the consequences on cellular uptake, as this rule of thumb 
was developed from a statistical analysis of non-natural drug molecules [53]. Additionally, the glycosylic bond of ACD005 might be subject of enzymatic hydrolysis depending on the environment within the cells, and the aglycon might be the active form. This hypothesis could explain the reduced activity of ACD005 in the assays performed with isolated membranes and the isolated Nox4 dehydrogenase domain (Nox4304-578) fragment. Besides ACD005, no Lipinski's Rule violations are observed. The two compounds, ACD042 and ACD084, discussed as specific Nox4 inhibitors, showed promising ADMET characteristics.

Nox 4 inhibitors have been described by others before. Thus, it was shown that extracts of Piper sarmentosum inhibit expression of Nox4 at the transcriptional level [26]. In an approach similar to the one chosen here [32], cell-based assays were used to characterise a set of synthetic compounds derived by medicinal chemistry for their ability to inhibit Nox4. Several hits with an $\mathrm{IC}_{50}$ (roughly equivalent to the $\mathrm{EC}_{50}$ described here) in the low micromolar range were reported, and Nox4 activity was entirely inhibited at a concentration of $10 \mu \mathrm{M}$ for each of their best hits. The compounds described here have comparable activity in cellbased assays, but since they are derived from edible plants, we expect better compatibility with ADMET criteria. Based on a screening campaign of substance libraries with Nox4-containing membranes, $\mathrm{K}_{\mathrm{i}}$ values in the two-digit nanomolar range were calculated for the best hits, including GKT137831 [25,33], which is currently being considered for clinical trials [28]. $\mathrm{K}_{\mathrm{i}}$ values in general describe the kinetic interaction between enzyme and substrate, and their calculation is rather difficult in such an approach, given the fact that the molar concentration of Nox4 in isolated membranes is unknown. The comparison to the inhibitory activity of compounds described here is further complicated by the fact that $\mathrm{EC}_{50}$ values for these compounds in cell-based assays are currently unknown. In a recent study with a cellular model of Nox4-dependent liver fibrosis, it was shown that inhibition of Nox4 activity in hepatocytes required GKT137831 at a concentration of $20 \mu \mathrm{M}$ [28], suggesting that the most active compounds (ACD005, ACD047, ACD053, ACD66, ACD067; see - Table 1) identified here are at least as active as GKT137831, which is considered the best available pharmacological Nox4 inhibitor to date [31].

\section{Acknowledgements \\ $\nabla$}

This work was supported by a grant from the Austrian Science Funds (FWF; P23742) and the European Union (integrated project MiMage). We thank V. Jaquet and K.-H. Krause for help with the broken cell assay and technical advice, B. Lener for initial help with the HEK-Nox4-based screening system, and J.E. Fuchs for technical and scientific support for in silico characterisation. We are grateful to $\mathrm{H}$. Stuppner, the $\mathrm{NCI}$, and Vasopharm AG for the kind gift of several compounds.

\section{Conflict of Interest \\ $\nabla$}

The authors declare no conflict of interest.

\section{Affiliations}

${ }^{1}$ Institute for Biomedical Aging Research (IBA), Austrian Academy of Sciences, Innsbruck, Austria

${ }^{2}$ Institute of General, Inorganic and Theoretical Chemistry and Center for Molecular Biosciences Innsbruck, University of Innsbruck, Innsbruck, Austria

${ }^{3}$ Tyrolean Cancer Research Institute at the Medical University of Innsbruck,

Innsbruck, Austria

${ }^{4}$ AnalytiCon Discovery GmbH, Potsdam, Germany

\section{References}

1 Perry BN, Govindarajan B, Bhandarkar SS, Knaus UG, Valo M, Sturk C, Carrillo CO, Sohn A, Cerimele F, Dumont D, Losken A, Williams J, Brown LF, Tan XL, Ioffe E, Yancopoulos GD, Arbiser JL. Pharmacologic blockade of angiopoietin-2 is efficacious against model hemangiomas in mice. J Invest Dermatol 2006; 126: 2316-2322

2 Lambeth JD. Nox enzymes and the biology of reactive oxygen. Nat Rev Immunol 2004; 4: 181-189

3 Lambeth JD, Krause KH, Clark RA. NOX enzymes as novel targets for drug development. Sem Immunopathol 2008; 30: 339-363

4 Geiszt M. NADPH oxidases: New kids on the block. Cardiovasc Res 2006; 71: 289-299

5 Martyn KD, Frederick LM, von Loehneysen K, Dinauer MC, Knaus UG. Functional analysis of Nox4 reveals unique characteristics compared to other NADPH oxidases. Cell Signal 2006; 18: 69-82

6 Luo Z, Chen Y, Chen S, Welch WJ, Andresen BT, Jose PA, Wilcox CS. Comparison of inhibitors of superoxide generation in vascular smooth muscle cells. Br J Pharmacol 2009; 157: 935-943

7 Bedard $K$, Krause $K H$. The NOX family of ROS-generating NADPH oxidases: Physiology and pathophysiology. Physiol Rev 2007; 87: 245313

8 Royerpokora B, Kunkel LM, Monaco AP, Goff SC, Newburger PE, Baehner $R L$, Cole FS, Curnutte JT, Orkin SH. Cloning the gene for an inherited human disorder - chronic granulomatous-disease - on the basis of its chromosomal location. Nature 1986; 322: 32-38

9 Krause $\mathrm{KH}$. Tissue distribution and putative physiological function of NOX family NADPH oxidases. Jpn J Infect Dis 2004; 57: S28-29

10 Chen K, Craige SE, Keaney Jr. JF. Downstream targets and intracellular compartmentalization in Nox signaling. Antiox Redox Signal 2009; 11: $2467-2480$

11 Geiszt M, Kopp JB, Varnai P, Leto TL. Identification of Renox, an NAD(P)H oxidase in kidney. Proc Natl Acad Sci USA 2000; 97: 8010-8014

12 Ago T, Kitazono T, Ooboshi H, Iyama T, Han YH, Takada J, Wakisaka M, Ibayashi S, Utsumi $H$, Iida $M$. Nox4 as the major catalytic component of an endothelial NAD(P)H oxidase. Circulation 2004; 109: 227-233

13 Yang S, Madyastha P, Bingel S, Ries W, Key L. A new superoxide-generating oxidase in murine osteoclasts. J Biol Chem 2001; 276: 5452-5458

14 Ellmark SH, Dusting GJ, Fui MN, Guzzo-Pernell N, Drummond GR. The contribution of Nox4 to NADPH oxidase activity in mouse vascular smooth muscle. Cardiovasc Res 2005; 65: 495-504

15 Cucoranu I, Clempus R, Dikalova A, Phelan PJ, Ariyan S, Dikalov S, Sorescu D. NAD(P)H oxidase 4 mediates transforming growth factor-beta1-induced differentiation of cardiac fibroblasts into myofibroblasts. Circ Res 2005; 97: 900-907

16 Gorin Y, Ricono JM, Kim NH, Bhandari B, Choudhury GG, Abboud HE. Nox4 mediates angiotensin II-induced activation of Akt/protein kinase B in mesangial cells. Am J Physiol Renal Physiol 2003; 285: F219-229

17 Mahadev K, Motoshima H, Wu X, Ruddy JM, Arnold RS, Cheng G, Lambeth $J D$, Goldstein BJ. The NAD(P)H oxidase homolog Nox4 modulates insulin-stimulated generation of $\mathrm{H} 2 \mathrm{O} 2$ and plays an integral role in insulin signal transduction. Mol Cell Biol 2004; 24: 1844-1854

18 Li J, Stouffs M, Serrander L, Banfi B, Bettiol E, Charnay Y, Steger K, Krause $K H$, Jaconi ME. The NADPH oxidase NOX4 drives cardiac differentiation: Role in regulating cardiac transcription factors and MAP kinase activation. Mol Biol Cell 2006; 17: 3978-3988

19 Uchizono Y, Takeya R, Iwase M, Sasaki N, Oku M, Imoto H, Iida M, Sumimoto $H$. Expression of isoforms of NADPH oxidase components in rat pancreatic islets. Life Sci 2006; 80: 133-139

20 Serrander L, Cartier L, Bedard K, Banfi B, Lardy B, Plastre O, Sienkiewicz $A$, Forro $L$, Schlegel $W$, Krause KH. NOX4 activity is determined by mRNA levels and reveals a unique pattern of ROS generation. Biochem J 2007; 406: 105-114

21 Sampson N, Koziel R, Zenzmaier C, Bubendorf L, Plas E, Jansen-Durr $P$ Berger $P$. ROS signaling by NOX4 drives fibroblast-to-myofibroblast differentiation in the diseased prostatic stroma. Mol Endocrinol 2011; 25: 503-515 
22 Schroder K, Zhang M, Benkhoff S, Mieth A, Pliquett R, Kosowski J, Kruse C, Luedike P, Michaelis UR, Weissmann N, Dimmeler S, Shah AM, Brandes RP. Nox4 is a protective reactive oxygen species generating vascular NADPH oxidase. Circ Res 2012; 110: 1217-1225

23 Li Y, Mouche S, Sajic T, Veyrat-Durebex C, Supale R, Pierroz D, Ferrari S, Negro F, Hasler U, Feraille E, Moll S, Meda P, Deffert C, Montet X, Krause $\mathrm{KH}$, Szanto I. Deficiency in the NADPH oxidase 4 predisposes towards diet-induced obesity. Int J Obes (Lond) 2012; 36: 1503-1513

24 Laleu B, Gaggini F, Orchard M, Fioraso-Cartier L, Cagnon L, HoungninouMolango S, Gradia A, Duboux G, Merlot C, Heitz F, Szyndralewiez C, Page $P$. First in class, potent, and orally bioavailable NADPH oxidase isoform 4 (Nox4) inhibitors for the treatment of idiopathic pulmonary fibrosis. J Med Chem 2010; 53: 7715-7730

25 Jaquet V, Scapozza L, Clark RA, Krause K-H, Lambeth JD. Small-molecule NOX inhibitors: ROS-generating NADPH oxidases as therapeutic targets. Antiox Redox Signal 2009; 11: 2535-2552

26 Ugusman A, Zakaria Z, Hui CK, Nordin NA. Piper sarmentosum inhibits ICAM-1 and Nox 4 gene expression in oxidative stress-induced human umbilical vein endothelial cells. BMC Complement Alternat Med 2011; 11: 31

27 Jaquet V, Marcoux J, Forest E, Leidal KG, McCormick S, Westermaier Y, Perozzo R, Plastre O, Fioraso-Cartier L, Diebold B, Scapozza L, Nauseef WM, Fieschi F, Krause KH, Bedard K. NADPH oxidase (NOX) isoforms are inhibited by celastrol with a dual mode of action. $\mathrm{Br} \mathrm{J}$ Pharmacol 2011; 164: 507-520

28 Jiang JX, Chen X, Serizawa N, Szyndralewiez C, Page P, Schroder K, Brandes RP, Devaraj S, Torok NJ. Liver fibrosis and hepatocyte apoptosis are attenuated by GKT137831, a novel NOX4/NOX1 inhibitor in vivo. Free Radic Biol Med 2012; 53: 289-296

29 Doussiere J, Gaillard J, Vignais PV. The heme component of the neutrophil NADPH oxidase complex is a target for aryliodonium compounds. Biochemistry 1999; 38: 3694-3703

30 O'Donnell BV, Tew DG, Jones OT, England PJ. Studies on the inhibitory mechanism of iodonium compounds with special reference to neutrophil NADPH oxidase. Biochem J 1993; 290: 41-49

31 Kim JA, Neupane GP, Lee ES, Jeong BS, Park BC, Thapa P. NADPH oxidase inhibitors: a patent review. Expert Opin Ther Pat 2011; 21: 1147-1158

32 Borbely G, Szabadkai I, Horvath Z, Marko P, Varga Z, Breza N, Baska F, Vantus T, Huszar M, Geiszt M, Hunyady L, Buday L, Orfi L, Keri G. Smallmolecule inhibitors of NADPH oxidase 4. J Med Chem 2010; 53: 67586762

33 Wind S, Beuerlein K, Eucker T, Muller H, Scheurer P, Armitage ME, Ho H, Schmidt $H$, Wingler K. Comparative pharmacology of chemically distinct NADPH oxidase inhibitors. Br J Pharmacol 2010; 161: 885-898

34 Gaggini F, Laleu B, Orchard M, Fioraso-Cartier L, Cagnon L, HoungninouMolango S, Gradia A, Duboux G, Merlot C, Heitz F, Szyndralewiez C, Page $P$. Design, synthesis and biological activity of original pyrazolo-pyridodiazepine, -pyrazine and -oxazine dione derivatives as novel dual Nox4/Nox1 inhibitors. Bioorg Med Chem 2011; 19: 6989-6999

35 Borbely G, Huszar M, Varga A, Futosi K, Mocsai A, Orfi L, Idei M, Mandl J, Keri G, Vantus T. Optimization of important early ADME(T) parameters of NADPH oxidase-4 inhibitor molecules. Med Chem 2012; 8: 174-181

36 Lener B, Koziel R, Pircher H, Hutter E, Greussing R, Herndler-Brandstetter $D$, Hermann $M$, Unterluggauer $H$, Jansen-Durr $P$. The NADPH oxidase Nox4 restricts the replicative lifespan of human endothelial cells. Biochem J 2009; 423: 363-374

37 Stockl P, Hutter E, Zwerschke W, Jansen-Durr P. Sustained inhibition of oxidative phosphorylation impairs cell proliferation and induces pre- mature senescence in human fibroblasts. Exp Gerontol 2006; 41: 674-682

38 Caldwell SE, McCall CE, Hendricks CL, Leone PA, Bass DA, McPhail LC. Coregulation of NADPH oxidase activation and phosphorylation of a 48-kD protein(s) by a cytosolic factor defective in autosomal recessive chronic granulomatous disease. J Clin Invest 1988; 81: 1485-1496

39 Grant JA, Gallardo M, Pickup B. A fast method of molecular shape comparison: A simple application of a Gaussian description of molecular shape. J Computat Chem 1996; 17: 1653-1666

40 Mills JE, Dean PM. Three-dimensional hydrogen-bond geometry and probability information from a crystal survey. J Comput Aided Mol Des 1996; 10: 607-622

41 Stielow C, Catar RA, Muller G, Wingler K, Scheurer P, Schmidt HH, Morawietz $H$. Novel Nox inhibitor of oxLDL-induced reactive oxygen species formation in human endothelial cells. Biochem Biophys Res Commun 2006; 344: 200-205

42 ten Freyhaus H, Huntgeburth M, Wingler K, Schnitker J, Baumer AT, Vantler M, Bekhite MM, Wartenberg M, Sauer H, Rosenkranz S. Novel Nox inhibitor VAS2870 attenuates PDGF-dependent smooth muscle cell chemotaxis, but not proliferation. Cardiovasc Res 2006; 71: 331-341

43 Stefanska J, Pawliczak R. Apocynin: molecular aptitudes. Mediators Inflamm 2008; DOI: 10.1155/2008/106507

44 Liou KT, Shen YC, Chen CF, Tsao CM, Tsai SK. The anti-inflammatory effect of honokiol on neutrophils: mechanisms in the inhibition of reactive oxygen species production. Eur J Pharmacol 2003; 475: 19-27

45 Banfi B, Tirone F, Durussel I, Knisz J, Moskwa P, Molnar GZ, Krause KH, Cox JA. Mechanism of Ca2+ activation of the NADPH oxidase 5 (NOX5). J Biol Chem 2004; 279: 18583-18591

46 Foti MC, Amorati $R$. Non-phenolic radical-trapping antioxidants. J Pharm Pharmacol 2009; 61: 1435-1448

47 Fato R, Bergamini C, Bortolus M, Maniero AL, Leoni S, Ohnishi T, Lenaz G. Differential effects of mitochondrial complex I inhibitors on production of reactive oxygen species. Biochim Biophys Acta 2009; 1787: 384-392

48 Helmcke I, Heumuller S, Tikkanen R, Schroder K, Brandes RP. Identification of structural elements in Nox1 and Nox4 controlling localization and activity. Antiox Redox Signal 2009; 11: 1279-1287

49 Lyle AN, Deshpande NN, Taniyama Y, Seidel-Rogol B, Pounkova L, Du P, Papaharalambus C, Lassegue B, Griendling KK. Poldip2, a novel regulator of Nox4 and cytoskeletal integrity in vascular smooth muscle cells. Circ Res 2009; 105: 249-259

50 Zhang L, Nguyen MV, Lardy B, Jesaitis AJ, Grichine A, Rousset F, Talbot M, Paclet MH, Qian G, Morel F. New insight into the Nox4 subcellular localization in HEK293 cells: first monoclonal antibodies against Nox4. Biochimie 2011; 93: 457-468

51 Nisimoto Y, Jackson HM, Ogawa H, Kawahara T, Lambeth JD. Constitutive NADPH-dependent electron transferase activity of the Nox4 dehydrogenase domain. Biochemistry 2010; 49: 2433-2442

52 Kleinschnitz C, Grund H, Wingler K, Armitage ME, Jones E, Mittal M, Barit $D$, Schwarz T, Geis C, Kraft P, Barthel K, Schuhmann MK, Herrmann AM, Meuth SG, Stoll G, Meurer S, Schrewe A, Becker L, Gailus-Durner V, Fuchs H, Klopstock T, de Angelis MH, Jandeleit-Dahm K, Shah AM, Weissmann N, Schmidt HH. Post-stroke inhibition of induced NADPH oxidase type 4 prevents oxidative stress and neurodegeneration. PLoS Biol 2010; 8: e1000479

53 Lipinski CA, Lombardo F, Dominy BW, Feeney PJ. Experimental and computational approaches to estimate solubility and permeability in drug discovery and development settings. Adv Drug Deliv Rev 2001; 46: $3-26$ 